Research article

Open Access

\title{
DAX-1 expression in human breast cancer: comparison with estrogen receptors ER- $\alpha$, ER- $\beta$ and androgen receptor status
}

\author{
Isabel Conde ${ }^{1}$, Juan M Alfaro ${ }^{1}$, Benito Fraile ${ }^{1}$, Antonio Ruíz ${ }^{2}$, Ricardo Paniagua ${ }^{1}$ \\ and Maria I Arenas ${ }^{1}$
}

${ }^{1}$ Department of Cell Biology and Genetics, University of Alcalá, Alcalá de Henares, Madrid, Spain

${ }^{2}$ Department of Pathology, Hospital Príncipe de Asturias, Alcalá de Henares, Madrid, Spain

Corresponding author: MI Arenas (e-mail: misabel.arenas@uah.es)

Received: 5 Nov 2003 Revisions requested: 19 Dec 2003 Revisions received: 14 Jan 2004 Accepted: 22 Jan 2004 Published: 13 Feb 2004

Breast Cancer Res 2004, 6:R140-R148 (DOI 10.1186/bcr766)

(c) 2004 Conde et al., licensee BioMed Central Ltd. This is an Open Access article: verbatim copying and redistribution of this article are permitted in all media for any purpose, provided this notice is preserved along with the article's original URL.

\begin{abstract}
Background: So far there have been no reports on the expression pattern of DAX-1 (dosage-sensitive sex reversal, adrenal hypoplasia critical region, on chromosome $\mathbf{X}$, gene 1) in human breast cells and its relationship to the estrogen receptors, ER- $\alpha$ and ER- $\beta$, and the androgen receptor (AR).

Methods: In this study we evaluated, by immunohistochemistry and Western blot analysis, the presence and distribution of DAX-1 in benign breast disease (BBD), in situ carcinoma $(\mathrm{CIS})$, and ductal and lobular breast carcinomas.

Results: In BBD and breast carcinomas, DAX-1 was present in both the nuclei and the cytoplasm of epithelial cells, although in infiltrative carcinomas the percentage of nuclear immunoreaction was higher than in CIS. An important relation was observed between DAX-1 and AR expression and between this orphan receptor and nodal status.

Conclusion: DAX-1 might modify the AR and ER- $\beta$ intracellular location, and because a direct positive relation between the expression of these three receptors was found it could be assumed that the presence of DAX-1 in neoplastic cells might indicate a possible failure of endocrine therapies.
\end{abstract}

Keywords: androgen receptor, breast cancer, DAX-1, estrogen receptor- $\alpha$, estrogen receptor- $\beta$

\section{Introduction}

Estrogens and androgens have a crucial role in the proliferation and progression of breast cancer [1]. Estrogens are potent mitogens that mediate its proliferative action through the induction of cyclin D1, the major regulator of entry into the G1 stage of the cell cycle, and promote the secretion of positive or negative paracrine growth signals by breast stroma cells, stimulating epithelial cells to proliferate $[2,3]$. Androgens might indirectly enhance breast cancer progression, because they are transformed into estrogens by the P450 cytochrome aromatase complex [4].

The biological effects of estrogens are mediated by four different estrogen receptor pathways: (1) classical liganddependent [5], (2) ligand-independent [6], (3) DNAbinding-independent [7], and (4) cell surface non-genomic signalling [8]. The first three pathways are mediated by two structurally related, but distinct, estrogen receptors (ERs): ER- $\alpha$ and ER- $\beta$. The expression patterns of these two receptors suggest that the genes encoding ER- $\alpha$ and ER- $\beta$ are differentially expressed in various tissues. ER- $\alpha$ expression seems to predominate in the female reproductive organs, whereas ER- $\beta$ expression predominates in non-reproductive organs and the male reproductive tract [9]. Both receptors have distinct cellular distributions, regulate separate sets of genes, and can oppose each other's actions on some genes; these differences suggest that the two receptors could have different effects [1].

Most human breast cancers express ER- $\alpha$, and this expression is generally considered a manifestation of their hormonal dependence. In breast cancer, the interruption

$\mathrm{AR}=$ androgen receptor; $\mathrm{BBD}=$ benign breast disease; $\mathrm{CIS}=$ in situ carcinoma; $\mathrm{DAX}=$ dosage-sensitive sex reversal, adrenal hypoplasia critical region, on chromosome $\mathrm{X} ; \mathrm{ER}=$ estrogen receptor; NDS = normal donkey serum; TBS $=$ Tris-buffered saline. 
of ER- $\alpha$ function is an effective therapeutic strategy [10]. Treatment with antiestrogens (tamoxifen) is now the firstline therapy for metastatic disease, and also adjuvant therapy after mastectomy. Despite the initial benefits of tamoxifen, most patients eventually relapse with tumors that are not only tamoxifen-resistant but are also stimulated by this agent [11]. Although some reports have shown that the expression of ER- $\beta$ protein decreases in neoplastic breast cells, suggesting that ER- $\beta$ could be an inhibitor of tumorigenesis [1,12], other studies have suggested that ER- $\beta$ expression is maintained during breast cancer progression $[3,13,14]$. The function of ER- $\beta$ in breast pathobiology is therefore unclear, partly because most studies have focused on its mRNA levels rather than on the protein [15].

The functional status of androgen receptor (AR) might be related to the pathogenesis and biological behavior of female breast cancer [16]. The tissues that express the lowest levels of AR are the adult breast, the colon, the lung, and the adrenal gland [17], and a low expression of AR has also been shown in breast tumors [18]. The molecular mechanism for AR expression loss in breast cancer is attributed to the active loss of an allele of the gene encoding AR; this loss might be crucial in predicting and influencing the response of breast cancer to endocrine therapy [16]. In addition, the loss of expression or function of this receptor is related to the activity of regulator proteins such as DAX-1 (dosage-sensitive sex reversal, adrenal hypoplasia critical region, on chromosome $\mathbf{X}$, gene 1), an unusual orphan member of the nuclear hormone receptor superfamily whose expression pattern is restricted to those tissues directly involved in steroid hormone production and reproductive function [19]. DAX1 functions as a global negative regulator of steroid hormone production by repressing the expression of multiple genes involved in the steroidogenic pathway [20]. The function of DAX-1 in females is unknown [21], and its role in breast cancer has not yet been studied.

The aim of this study was to elucidate the expression pattern of DAX-1, ER- $\alpha, E R-\beta$, and AR in different types of breast carcinoma by immunohistochemical techniques and Western blot analysis, to improve our knowledge of the influence of these receptors in the development and progression of breast cancer and their possible influence in endocrine therapies.

\section{Materials and methods Materials}

Breast samples used in this study were obtained by total or partial mastectomy and included a total of 67 cases: 14 cases of in situ carcinoma (CIS), 24 of infiltrative ductal carcinoma, 15 of infiltrative lobular carcinoma, and 14 of benign proliferative diseases including ductal and lobular hyperplasia, apocrine metaplasia, fibroadenoma, and fibro- cystic changes. Benign proliferative diseases and $\mathrm{CIS}$ were observed in perimenopausal women (average \pm SEM age $45.81 \pm 13.46$ years), whereas infiltrative and invasive tumors belonged to postmenopausal women of higher average age (59.93 \pm 14.89 years). All infiltrative tumor samples were classified by the TNM system [22]. After surgery, the hormonal status of each invasive carcinomatous lesion was evaluated, and antiestrogen treatment (tamoxifen) was applied in the positive cases for its cognate receptors. Removal of tissues and the study of archive samples were performed with the consent of the patients' relatives and permission of the Ethics Committee of the Príncipe de Asturias Hospital, Alcalá de Henares, Spain.

Each specimen was divided into two approximately equal portions: one was processed for immunohistochemistry (fixed with 10\% formalin and embedded in paraffin), and the other was frozen in liquid nitrogen and maintained at $-80^{\circ} \mathrm{C}$ for Western blot analysis.

\section{Immunohistochemistry}

Sections $5 \mu \mathrm{m}$ thick were processed by using the avidinbiotin-peroxidase complex (ABC) method. After the removal of paraffin, sections were hydrated and incubated for 20 min in $0.3 \% \mathrm{H}_{2} \mathrm{O}_{2}$ to inhibit endogenous peroxidase activity; to retrieve the antigen the sections were incubated with $0.1 \mathrm{M}$ citrate buffer $(\mathrm{pH} 6)$ for 30 seconds in a conventional pressure cooker [23]. After being rinsed in Tris-buffered saline (TBS), the slides were incubated with $3 \%$ normal donkey serum (NDS) in TBS for $30 \mathrm{~min}$ to prevent non-specific binding of the first antibody. The sections were then incubated with mouse monoclonal antiER- $\alpha$ (Novocastra Laboratories Ltd, UK) (1:60 dilution), rabbit polyclonal anti-ER- $\beta$ (Chemicon, Temecula, CA, USA) (1:500 dilution), rabbit polyclonal anti-AR (Novocastra) (1:50 dilution), and rabbit polyclonal anti-DAX-1 (Santa Cruz Biotechnology, Santa Cruz, CA, USA) (1:20 dilution) primary antibodies, each diluted in TBS containing $0.3 \%$ NDS. Sections were incubated overnight with primary antibodies: at $37^{\circ} \mathrm{C}$ for ER- $\alpha$, ER- $\beta$, and DAX-1, and at $20^{\circ} \mathrm{C}$ for $A R$.

The sections were then washed in TBS and incubated for 1 hour with either pig anti-rabbit (for ER- $\beta, A R$, and DAX-1) or rabbit anti-mouse (for ER- $\alpha$ ) biotinylated immunoglobulins (Dako, Barcelona, Spain), diluted 1:400 in TBS plus $0.3 \%$ NDS. After being washed in TBS, the sections were incubated with avidin-biotin-peroxidase complex (Dako) for 1 hour and developed with 3,3'-diaminobenzidine (DAB), using the glucose oxidase-DAB-nickel intensification method [24]. Sections were then dehydrated and mounted in DePex (Probus, Badalona, Spain).

To assess the specificity of the immunoreaction, negative and positive controls were used. For negative controls, adjacent sections of each pathology (benign proliferative 
diseases, and ductal and lobular carcinomas) were incubated with preimmune serum depending on the first antibody (mouse serum [for ER- $\alpha$ ] and rabbit serum [for ER- $\beta$, $A R$, and DAX-1]), or using the antibody preabsorbed with an excess of purified antigens, or omitting the primary antibody. As positive controls, sections of rat ovary for ER- $\alpha$, human testes for ER- $\beta$, and human prostate for the AR and DAX-1 were processed with the same antibody.

\section{Immunoblotting}

For Western blot analysis, tissues were homogenized in extraction buffer $(10 \mathrm{mM}$ Tris- $\mathrm{HCl}, \mathrm{pH} 7.6,10 \mathrm{mM} \mathrm{KCl}$, $1 \mathrm{mM}$ 1,4-dithiothreitol, and 0.2 M EDTA, pH 8) in addition to a cocktail of protease inhibitors ( $1 \mathrm{mM}$ phenylmethanesulfonyl fluoride, $10 \mu \mathrm{g} / \mathrm{ml}$ leupeptine, and $1 \mu \mathrm{g} / \mathrm{ml}$ aprotinine) and phosphatase inhibitors $(200 \mu \mathrm{g} / \mathrm{ml}$ sodium fluoride and $50 \mu \mathrm{g} / \mathrm{ml}$ sodium orthovanadate) in the presence of $0.5 \%$ Triton X-100 and 0.1\% SDS. Homogenates were centrifuged for $10 \mathrm{~min}$ at $10,000 \mathrm{rpm}$ at $4^{\circ} \mathrm{C}$. Supernatants were mixed with an equivalent volume of SDS buffer (10\% SDS in Tris/ $\mathrm{HCl}, \mathrm{pH} 8$, containing 50\% glycerol, $0.1 \mathrm{mM} 2$-mercaptoethanol, and $0.1 \%$ bromophenol blue). The mixture was then denatured for $4 \mathrm{~min}$ at $96^{\circ} \mathrm{C}$, and $70 \mu \mathrm{g}$ aliquots of protein were subjected to SDSpolyacrylamide-gel electrophoresis (SDS-PAGE; 9\% polyacrylamide). After SDS-PAGE, proteins were transferred to nitrocellulose membranes $(0.2 \mu \mathrm{m}$ pore size) in transfer buffer (25 mM Tris- $\mathrm{HCl}, 192 \mathrm{mM}$ glycine, $0.1 \%$ SDS, and $20 \%$ methanol) for 4 hours at $250 \mathrm{~mA}$ constant current. In brief, the blots for ERs were blocked in 5\% Blotto (Santa Cruz) for $50 \mathrm{~min}$; the sheets for $\mathrm{AR}$ and DAX-1 were blocked in 5\% Blotto in addition to 1\% NDS for $30 \mathrm{~min}$. After being blocked, blots were incubated overnight with primary antibodies diluted 1:400 (ER- $\alpha$ ), $1: 4000$ (ER- $\beta$ ), or 1:200 (AR and DAX-1) in 1:9 blocking solution at room temperature (for ER- $\alpha, E R-\beta$, and $A R$ ) or at $37^{\circ} \mathrm{C}$ (for DAX-1).

After extensive washing with TBS/Tween 20, the membranes were incubated with the following peroxidase-conjugated secondary antibodies, diluted in 1:9 blocking solution: goat anti-mouse for ER- $\alpha$, or goat anti-rabbit for ER- $\beta$ and DAX-1 (Chemicon) at 1:4000. For AR the sheets were incubated with the pig anti-rabbit biotinylated immunoglobulins (Dako) at 1:2000 and afterwards an extensive wash with streptavidin-peroxidase (Zymed Laboratories Inc, South San Francisco, CA, USA) at 1:8000 dilution in the same 1:9 blocking solution. Finally, the membranes were developed with an enhanced chemiluminescence kit, in accordance with the procedure described by the manufacturer (Amersham, Little Chalfont, Buckinghamshire, UK).

\section{Statistical analysis}

The possible correlation between the principal parameters mas (patient age, axillary lymph node status, disease-free duration, and DAX-1, ER- $\alpha$, ER- $\beta$, and AR expression), were evaluated by means of a multivariance analysis of the principal components. The purpose was to obtain a small number of linear combinations from the seven variables. These combinations account for most of the variability in the data with minimum loss of real data.

The results of principal components analysis were confirmed by determination of the correlation of DAX-1 expression and the status of ER- $\alpha, E R-\beta, A R$, and several clinicopathological factors, by using Fisher's exact test or the $\chi^{2}$ test (two-tailed).

Correlation of the DAX-1 expression between the different pathologies studied was calculated with the non-parametric Spearman correlation coefficient. Statistical analysis was performed with a StatGraphics computer program.

\section{Results \\ Western blot analysis}

The results of the Western blot analysis are shown in Fig. 1. For each antibody, only a single band was found at the corresponding molecular mass: $65 \mathrm{kDa}$ for $\mathrm{ER}-\alpha$, $59 \mathrm{kDa}$ for ER- $\beta, 130 \mathrm{kDa}$ for AR, and $55 \mathrm{kDa}$ for DAX-1. For ER- $\alpha$, a similar expression was observed in benign diseases (Fig. 1a) and in CIS (Fig. 1a). Immunoreaction was more intense in cases presenting infiltrative ductal carcinoma (Fig. 1a) and infiltrative lobular carcinoma (Fig. 1a). The band corresponding to ER- $\beta$ was only observed in infiltrative lobular carcinoma (Fig. 1b). AR and DAX-1 immunoreactions were observed in benign diseases as well as in both cancer types (Fig. 1c,d).

\section{Immunohistochemical study of control sections}

The immunohistochemical study showed no reaction in the negative controls incubated with the preimmune serum, using the antibody preabsorbed with an excess of purified antigen, or omitting the primary antibody. Immunostaining of rat ovary, human testis, and human prostate sections was always positive.

\section{Immunohistochemical study of ER- $\alpha$}

The results obtained by immunohistochemistry are summarized in Table 1.

In benign breast diseases no immunoreaction to ER- $\alpha$ was observed (Fig. 2a). In CIS, 42.86\% of cases showed nuclear immunoreaction to this receptor (Fig. 2b), and $28.57 \%$ presented cytoplasmic reaction. In ductal infiltrative carcinomas (Fig. 2c) the percentage of cases immunostained in the nuclei increased (62.5\%), but those cases showing cytoplasmic reaction decreased (12.5\%). Infiltrative lobular carcinomas showed nuclear labelling in $60 \%$ of cases (Fig. 2 d) and cytoplasmic immunoreaction in $40 \%$. 
Figure 1

\section{BBD CIS IDC ILC}

(a)

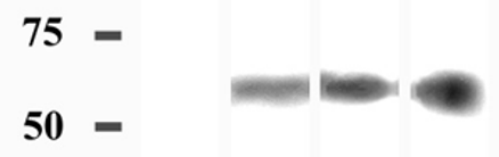

(b)

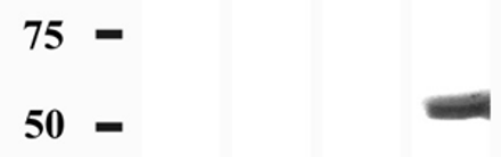

(c)

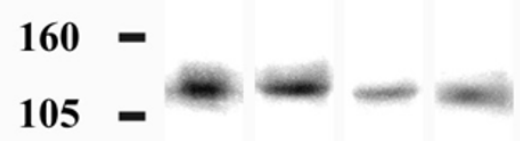

(d)

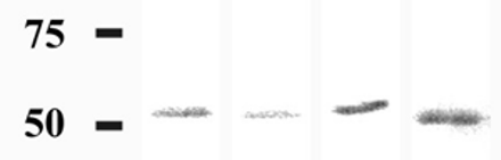

Immunoblots of ER- $\alpha$ (a), ER- $\beta$ (b), AR (c), and DAX-1 (d) in human breast. Relative molecular masses are shown at the left. Each blot is representative of its respective group. For all panels: lane 1, benign breast disease; lane 2 , in situ carcinoma; lane 3 , infiltrative ductal carcinoma; lane 4, infiltrative lobular carcinoma.

\section{Immunohistochemical study of ER- $\beta$}

In benign breast diseases no ER- $\beta$ expression was found (Fig. 2e). In CIS, immunostaining was observed in $28.57 \%$ of cases, always in the cytoplasm (Fig. 2f).
In infiltrative ductal carcinoma the percentage of cases showing nuclear immunoreaction was similar to that observed in CIS. However, the percentage of cases showing cytoplasmic labelling (Fig. 2g) was increased (37.5\%). In infiltrative lobular carcinoma (Fig. $2 \mathrm{~h}$ ) the percentage of cases showing cytoplasmic immunoreaction was even higher (60\%).

\section{Immunohistochemical study of AR}

In the benign diseases no nuclear immunoreaction was observed (Fig. 2i), although cytoplasmic immunoreaction was observed in a small proportion of cases (21.4\%). In the remaining pathologies only a few cases showed nuclear immunostaining, and the number of cases showing cytoplasmic immunoreaction increased from CIS (28.57\%; Fig. 2j) and infiltrative ductal carcinomas (37.5\%; Fig. 2k) to infiltrative lobular carcinomas (60\%; Fig. 2l).

\section{Immunohistochemical study of DAX-1}

All pathologies studied, including benign breast diseases, showed either nuclear or cytoplasmic immunoreaction to DAX-1 (Fig. 2m-p). The cytoplasmic immunoreaction was granular and appeared in epithelial cells (Fig. 2n).

The highest percentages of cases showing positive immunoreaction (in the nucleus or in the cytoplasm) were found in cancer patients (ductal and lobular). Analysing the DAX-1 immunoexpression between the different pathologies studied by using the non-parametric Spearman correlation coefficient, we found that the only statistically significant difference was between benign diseases and infiltrative lobular carcinomas $(P=0.037, P<0.05)$.

\section{Association of DAX-1 expression with ER- $\alpha$, ER- $\beta$, and} AR status and other clinicopathological factors

The results of the principal components analysis, presented as a two-dimensional component plot (Fig. 3), show the weights for the principal components analysed (patient age, axillary lymph node status, disease-free duration, and DAX1 , ER- $\alpha, E R-\beta$, and AR immunoexpression). Each variable is represented by a point and the reference lines are drawn at 0 for each dimension. A weight close to 0 therefore indicates that the variable contributes little to the component. All of these variables explain the $53.85 \%$ of variability in the original data. The variables that form an acute angle with respect to the origin are more correlated. Thus, the most related variables were $A R$ and $D A X-1$ expression, although relations between DAX-1 and nodal status, AR and ER- $\beta$, and between ER- $\alpha$ and both patient age and disease-free duration were also found. However, no relation was found between the nodal status and disease-free duration or ER- $\alpha$ because they were in opposite quadrants.

When the Fisher's exact or $\chi^{2}$ test was used (Table 2), a statistically significant difference was observed between DAX-1 nuclear expression and nodal status $(P<0.05)$ 


\begin{tabular}{|c|c|c|c|c|c|c|c|c|}
\hline \multirow[b]{2}{*}{ Protein } & \multicolumn{2}{|c|}{$\operatorname{BBD}(n=14)$} & \multicolumn{2}{|c|}{$\mathrm{CIS}(n=14)$} & \multicolumn{2}{|c|}{$\begin{array}{l}\text { Infiltrative ductal } \\
\text { carcinoma }(n=24)\end{array}$} & \multicolumn{2}{|c|}{$\begin{array}{l}\text { Infiltrative lobular } \\
\text { carcinoma }(n=15)\end{array}$} \\
\hline & $\mathrm{N}$ & $\mathrm{C}$ & $\mathrm{N}$ & $\mathrm{C}$ & $\mathrm{N}$ & $\mathrm{C}$ & $\mathrm{N}$ & $\mathrm{C}$ \\
\hline ER- $\alpha$ & $0(0)$ & $0(0)$ & $6(42.86)$ & $4(28.57)$ & 15 (62.5) & $3(12.5)$ & $9(60)$ & $6(40)$ \\
\hline ER- $\beta$ & $0(0)$ & $0(0)$ & $0(0)$ & $4(28.57)$ & $0(0)$ & $9(37.5)$ & $0(0)$ & $9(60)$ \\
\hline AR & $0(0)$ & $3(21.4)$ & $1(7.15)$ & $4(28.57)$ & 3 (12.5) & 9 (37.5) & $1(6.66)$ & $9(60)$ \\
\hline DAX-1 & $3(21.42)$ & 5 (35.72) & $3(21.43)$ & $4(28.57)$ & 9 (37.5) & $6(25)$ & $7(46.66)$ & 5 (33.33) \\
\hline
\end{tabular}

Results in parentheses are percentages. AR, androgen receptor; BBD, benign breast diseases; C, cytoplasmic immunoreaction; CIS, in situ carcinomas; ER, estrogen receptor; $\mathrm{N}$, nuclear immunostaining.

and between DAX-1 nuclear and cytoplasmic expression and AR expression $(P<0.05$ and $P<0.001$, respectively).

\section{Discussion}

In previous reports, ER- $\alpha$ mRNA was detected in $92 \%$ of breast cancers, and ER- $\beta$ mRNA in 85\%; however, after protein translation, the percentages of cases decreased to $72 \%$ and $32 \%$, respectively [25]. This agrees with the observation of a decrease in ER- $\beta$ protein expression when the neoplastic cells begin to proliferate in proliferative preinvasive mammary tumors [12]. This decreased level of ER- $\beta$ protein, associated with cell proliferation, suggests a protective effect of ER- $\beta$ against the mitogenic activity of estrogens in mammary premalignant lesions [12]. In comparison, the decrease in ER- $\alpha$ protein expression after translation is lower, suggesting a higher receptivity to estrogens in these preinvasive tumor tissues, and an increased risk of tumorigenesis [26].

In this study we observed that a high proportion of infiltrative lobular carcinoma cases (60\%) showed nuclear immunostaining for ER- $\alpha$; the percentage was similar for infiltrative ductal carcinomas (62.5\%). This finding contrasts with the absence of immunoreaction in BBD samples. These results are in agreement with those observed by Palmieri and colleagues [3], who found low ER- $\alpha$ expression in fibrocystic disease and high ER- $\alpha$ expression in invasive ductal cancer.

Our data revealed no correlation between the expression of ER- $\alpha$ and that of ER- $\beta$; thus, all breast carcinomas analysed gave a negative nuclear reaction to ER- $\beta$, although cytoplasmic expression was found in some cases. This cytoplasmic location suggests that ER- $\beta$ is inactive because of the absence of a ligand, because these receptors can escape rapidly from the nucleus and shuttle repeatedly between nucleus and cytoplasm [27]. It has also been reported that, in endothelial cells, ER- $\beta$ can act via the cytoplasm through a novel pathway [28]. This diol-activated ER- $\alpha$ and ER- $\beta$ receptors and induces the transcriptional activation of Stat-regulated promoters; the pathway involves an agonist-bound ER-activated phosphorylation cascade, resulting in the nuclear transcriptional activation of target transcription factors [28].

Jarvinen and colleagues [13] found that $60 \%$ of breast tumors were ER- $\beta$-positive and that this expression was significantly associated with negative axillary node status and low grade of malignancy. Mann and colleagues [29] reported that the expression of ER- $\beta$ in more than $10 \%$ of cancer cells was associated with better survival. However, Dotzlaw and colleagues [30] showed that tumors coexpressing ER- $\alpha$ and ER- $\beta$ were node-positive and tended to have higher grade of malignancy. These data suggest that ER- $\beta$ might have a role in breast cancer cells and that this role depends on the presence or absence of ER- $\alpha$ expression.

The expression of ER- $\alpha$ and ER- $\beta$ in breast cancer cells is crucial in determining whether antiestrogen therapy would be efficient, because some antiestrogenic drugs such as 4$\mathrm{OH}$-tamoxifen are more competitive than other estrogenic substance antagonists of ER- $\beta$ [31], and do not display agonist activity when the receptor concentration increases. ER- $\beta$ therefore seems to suppress the partial agonist activity of tamoxifen on ER- $\alpha$ [32], so the response to this treatment will evidently depend on the distribution of these receptors. In our study, we found that those patients that showed ER- $\alpha$ expression were usually not the same as those who showed ER- $\beta$ expression, and most ER- $\alpha^{+} / E R$ $\beta^{-}$patients had a poor prognosis and a worse response to hormonal therapy than ER- $\alpha^{+} / \mathrm{ER}-\beta^{+}$patients.

In postmenopausal women, only about $25 \%$ of circulating testosterone arises from that secreted by the ovary. The remaining $75 \%$ comes from circulating precursors derived from either the adrenal cortex or the ovary [33]. Circulating levels of these androgenic steroids might be important in the maintenance of local estrogen synthesis. Adrenal 


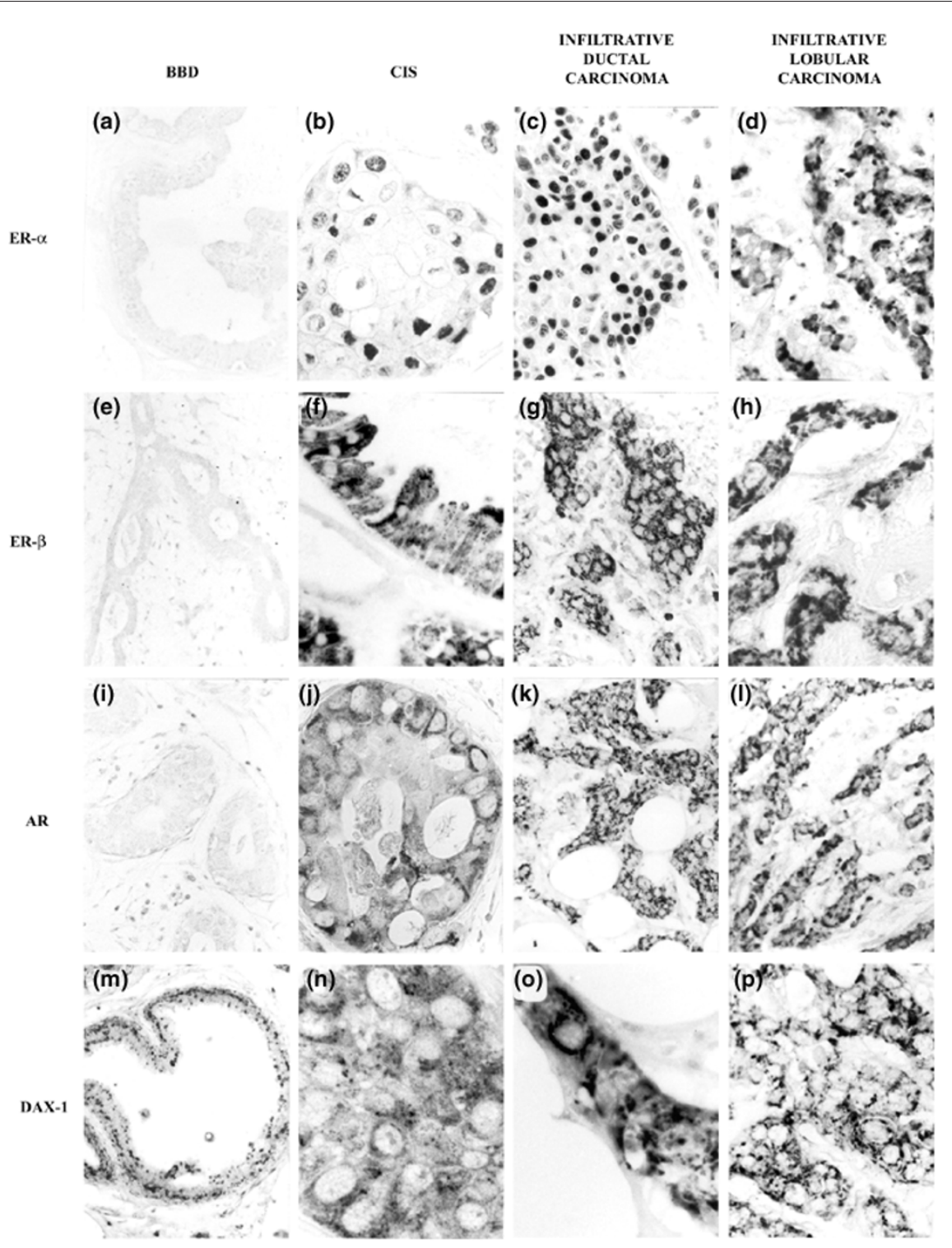

Expression of estrogen receptors ER- $\alpha$, ER- $\beta$, androgen receptor (AR) and DAX-1 in human breast. (a-d) Immunohistochemistry of ER- $\alpha$. (a) Negative immunoreaction in ductal hyperplasia (magnification $\times 300$ ). (b) Sample of ductal carcinoma in situ (CIS) showing a strong immunolabelling of ER- $\alpha$ in the nuclei of neoplastic cells (magnification $\times 500$ ). (c) A strong nuclear reactivity to ER- $\alpha$ antibody was observed in samples of infiltrative ductal carcinoma (IDC; magnification $\times 250$ ). (d) ER- $\alpha$ was observed in the cytoplasm of some cells in infiltrative lobular carcinoma (ILC; magnification $\times 300)$. (e-h) Immunohistochemistry of ER- $\beta$. (e) Fibroadenoma was always negative to ER- $\beta$ (magnification $\times 300$ ). (f) Ductal CIS showing an intense cytoplasmic immunoreaction to ER- $\beta$ (magnification $\times 400$ ). (g) Positive reaction to ER- $\beta$ in the cytoplasm of IDC cells (magnification $\times 250$ ). (h) ILC showing cytoplasmic reaction to ER $-\beta$ (magnification $\times 450)$. (i-l) Immunohistochemistry of androgen receptor (AR). (i) Negative reaction to AR antibody in hyperplasia (magnification $\times 300)$. In CIS (j) (magnification $\times 400)$ and IDC (k) (magnification $\times 200)$, cytoplasmic immunolabelling of AR was observed. (I) ILC showing cytoplasmic immunostaining of AR (magnification $\times 200$ ).

$(m-p)$ Immunohistochemistry of DAX-1. An intense cytoplasmic reaction with granular pattern was observed in cases from ductal hyperplasia (m) (magnification $\times 200)$, CIS ( $\mathrm{n})$ (magnification $\times 600)$, IDC (o) (magnification $\times 600)$, and ILC (p) (magnification $\times 350)$. BBD, benign breast diseases.

androgens might therefore promote breast cancer, although higher levels of these hormones might prevent it [34]. Androgens have two primary effects on mammary tumor cells: (1) in the absence of estrogens they stimulate the growth of breast cancer cells by binding to ER- $\alpha$, and this effect can be blocked by treatment with antiestrogen; (2) in the presence of estrogens they act as antiestrogens to inhibit the stimulation of the growth of breast cancer cells by estrogen (this effect is exerted through AR and can be blocked by antiandrogens) [4]. 


\section{Figure 3}

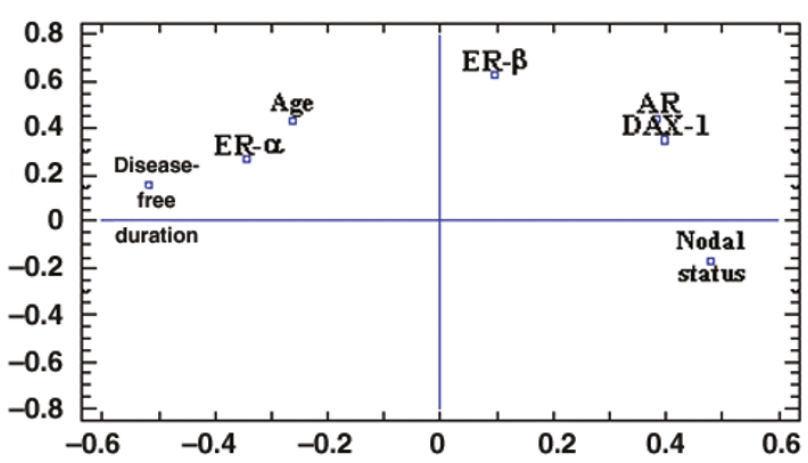

Two-dimensional component plot showing the results of the principal components analysis obtained from the 39 patients with infiltrative carcinoma. A close correlation between DAX-1 immunoexpression, nodal status, and AR expression is observed. Component 1 is on the $x$-axis; component 2 is on the $y$-axis.
It has been reported that up to $80 \%$ of human breast tumors are AR-positive and that AR-negative status is correlated with the aggressive features of breast cancers [35], because patients with AR-negative tumors had a significantly poorer response rate to hormone therapy than those with positive tumors [16]. In contrast with these findings, in this study we observed nuclear immunostaining to AR in $7.15 \%$ of CIS, $12.5 \%$ of infiltrative ductal carcinomas, and only $6.66 \%$ of infiltrative lobular carcinomas. However, the percentage of cytoplasmic reaction to $A R$ in these three pathologies was higher, suggesting that this receptor forms a multiprotein complex in the cytoplasm and, in the presence of ligand, AR becomes tightly bound in the nucleus [36]. This cytoplasmic location of AR could be explained by the presence of DAX-1. Recent studies have suggested that DAX-1 is not exclusively a nuclear orphan receptor but can be also detected mainly in the cytoplasm, functioning as a potent corepressor for estrogen receptors in mammalian cells, presumably by the

Table 2

\begin{tabular}{|c|c|c|c|c|c|c|}
\hline Parameter & $n$ & Negative & Nuclear location & $P$ & Cytoplasmic location & $P$ \\
\hline \multicolumn{7}{|l|}{ Age (years) } \\
\hline$\leq 50$ & 11 & 5 & 4 & & 2 & \\
\hline$>50$ & 28 & 9 & 11 & 0.699 & 8 & 0.652 \\
\hline \multicolumn{7}{|l|}{ TNM class } \\
\hline $\mathrm{T}_{1}$ & 19 & 10 & 7 & & 2 & \\
\hline $\mathrm{T}_{2}$ & 16 & 6 & 6 & & 4 & \\
\hline $\mathrm{T}_{3}^{2}$ & 2 & 1 & 1 & & 0 & \\
\hline $\mathrm{T}_{4}$ & 2 & 0 & 0 & 0.8486 & 2 & 0.216 \\
\hline \multicolumn{7}{|c|}{ Nodal status (\%) } \\
\hline$\leq 33$ & 26 & 14 & 6 & & 6 & \\
\hline 33-90 & 10 & 2 & 7 & & 1 & \\
\hline$>90$ & 3 & 0 & 1 & $<0.05$ & 2 & 0.1439 \\
\hline \multicolumn{7}{|c|}{ Histological type } \\
\hline Ductal & 24 & 10 & 9 & & 5 & \\
\hline Lobular & 15 & 4 & 6 & 0.699 & 5 & 0.4028 \\
\hline \multicolumn{7}{|c|}{ Disease-free duration (months) } \\
\hline $5-20$ & 3 & 0 & 1 & & 2 & \\
\hline $20-30$ & 10 & 2 & 5 & & 3 & \\
\hline$>30$ & 26 & 11 & 9 & 0.3081 & 6 & 0.1713 \\
\hline \multicolumn{7}{|l|}{ ER- $\alpha$} \\
\hline- & 10 & 5 & 3 & & 2 & \\
\hline $\mathrm{C}$ & 9 & 2 & 2 & & 5 & \\
\hline $\mathrm{N}$ & 20 & 7 & 10 & 0.6077 & 3 & 0.1649 \\
\hline \multicolumn{7}{|l|}{ ER- $\beta$} \\
\hline - & 23 & 9 & 7 & & 7 & \\
\hline $\mathrm{C}$ & 13 & 5 & 6 & & 3 & \\
\hline $\mathrm{N}$ & 3 & 1 & 2 & 0.7138 & 0 & 0.6766 \\
\hline \multicolumn{7}{|l|}{ AR } \\
\hline - & 20 & 12 & 6 & & 2 & \\
\hline $\mathrm{C}$ & 17 & 2 & 7 & & 8 & \\
\hline $\mathrm{N}$ & 2 & 0 & 2 & $<0.05$ & 0 & $<0.001$ \\
\hline
\end{tabular}


direct occupation of the coactivator-binding surface and the subsequent recruitment of additional corepressor [37]. Moreover, Holter and colleagues [21] demonstrated that DAX-1 could sequester AR in the cytoplasm, inhibiting its activation, presumably by both transcriptional and nontranscriptional mechanisms, indicating a possible function of DAX-1 as a cytoplasmic retention factor. We have found an important relation between AR and DAX-1 expression in infiltrative carcinomas with the use of principal components analysis and Fisher's exact test, the significance being higher in the cytoplasmic location frequencies. This correspondence suggests that this orphan receptor might be a cytoplasmic retention factor and tethers AR.

DAX-1 is also able to sequester ER- $\beta$ in the cytoplasm in an agonist-dependent manner [37]. Like ER- $\beta$, DAX-1 seems to be a candidate regulator of $A R$ expression in tissues such as prostate and ovary [38]; it can be also assumed that this regulation occurs in breast tissues because we have observed a statistically significant correlation between ER- $\beta$ expression and that of AR.

Interestingly, the hormonal steroidogenic pathway seems to be specifically inhibited by DAX-1 in steroid-producing cells [21]. The modulation of DAX-1 expression by diverse bioactive substances and physiological conditions probably represents an important mechanism for controlling steroid hormone production [20].

\section{Conclusion}

DAX-1 might modify the intracellular location of AR and ER- $\beta$ but not that of ER- $\alpha$. Because we have observed a direct positive relation between nodal status and DAX-1 expression, it can be assumed that the presence of this receptor in neoplastic cells might indicate a possible failure of endocrine therapies; it would therefore be advisable to study DAX-1 expression in those patients presenting with breast cancer before hormonal therapy application, and to develop new therapeutic strategies that can modulate the action of this receptor to prevent the subsequent resistance that the neoplastic cells acquire.

\section{Competing interests}

None declared.

\section{Acknowledgements}

We thank Dr MC Alonso, from the Department of Mathematics of the University of Alcalá, for statistical analysis. I Conde is supported by a grant from the University of Alcalá.

\section{References}

1. Lazennec G, Bresson D, Lucas A, Chauveau C, Vignon F: ER $\beta$ inhibits proliferation and invasion of breast cancer cells. Endocrinology 2001, 142:4120-4130.

2. Anderson E, Clarke RB, Howell A: Estrogen responsiveness and control of normal human breast proliferation. $J$ Mammary Gland Biol Neoplasia 1998, 3:3-5.

3. Palmieri C, Cheng GJ, Saji S, Zelada-Hedman M, Wärri A, Weihua Z, Van Noorden S, Wahlstrom T, Coombes RC, Warner
M, Gustafsson JA: Estrogen receptor beta in breast cancer. Endocrine-Related Cancer 2002, 9:1-13.

4. Burak WE Jr, Quinn AL, Farrar WB, Brueggeneier RW: Androgens influence estrogen-induced responses in human breast carcinoma cells through cytochrome $\mathbf{P} 450$ aromatase. Breast Cancer Res Treat 1997, 44:57-64.

5. McKenna NJ, Lanz RB, O'Malley BW: Nuclear receptor coregulators: cellular and molecular biology. Endocr Rev 1999, 20: 321-344.

6. Curtis SW, Washburn T, Sewall C, DiAugustine R, Lindzey J, Couse JF, Korach KS: Physiological coupling of growth factor and steroid receptor signalling pathways: estrogen receptor knockout mice lack estrogen-like response to epidermal growth factor. Proc Natl Acad Sci USA 1996 93:12626-12630.

7. Uht RM, Anderson CM, Webb P, Kushner PJ: Transcriptional activities of estrogen and glucocorticoid receptors are functionally integrated at the AP-1 response element. Endocrinology 1997, 138:2900-2908.

8. Kousteni S, Bellido T, Plotkin LI, O'Brien CA, Bodenner DL, Han L, Han K, DiGregorio GB, Katzenellenbogen JA, Katzenellenbogen BS, Roberson PK, Weinstein RS, Jilka RL, Manolagas SC: Nongenotropic, sex-nonspecific signalling through the estrogen or androgen receptors: dissociation from transcriptional activity. Cell 2001, 104:719-730.

9. Couse JF, Lindzey J, Grandien K, Gustafsson JA, Korach KS: Tissue distribution and quantitative analysis of estrogen receptor-alpha (ER alpha) and estrogen receptor-beta (ER beta) messenger ribonucleic acid in the wild-type and ER alpha-knockout mouse. Endocrinology 1997, 138:4613-4621.

10. McGuire WL: Endocrine therapy of breast cancer. Annu Rev Med 1975, 26:353-363.

11. MacGregor Jl, Jordan VC: Basic guide to the mechanisms of antiestrogen action. Pharmacol Rev 1998, 50:151-196.

12. Roger $P$, Sahla ME, Makela S, Gustafsson JA, Baldet $P$, Rochefort $\mathrm{H}$ : Decreased expression of estrogen receptor $\beta$ protein in proliferative preinvasive mammary tumours. Cancer Res 2001, 61:2537-2541.

13. Jarvinen TA, Pelto-Huikko $M$, Holli $K$, Isola J: Estrogen receptor beta is coexpressed with ER alpha and PR and associated with nodal status, grade, and proliferation rate in breast cancer. Am J Pathol 2000, 156:29-35.

14. Speirs V, Kerin MJ: Prognostic significance of oestrogen receptor beta in breast cancer. Br J Surg 2000, 87: 405-409.

15. Speirs V: Oestrogen receptor beta in breast cancer: good, bad or still too early to tell? J Patho/ 2002, 197:143-147.

16. Shan L, Yang Q, Nakamura M, Nakamura Y, Mori I, Sakurai T, Kakudo K: Active allele loss of the androgen receptor gene contributes to loss of androgen receptor expression in female breast cancers. Biochem Biophys Res Commun 2000, 275: 488-492.

17. Wilson $\mathrm{CM}, \mathrm{McPhaul} \mathrm{MJ}$ : $\mathbf{A}$ and $\mathbf{B}$ forms of the androgen receptor are expressed in a variety of human tissues. Mol Cell Endocrinol 1996, 120:51-57.

18. Brys M, Wojcik M, Romanowicz-Makowska H, Krajewska WM: Androgen receptor status in female breast cancer: RT-PCR and Western blot studies. J Cancer Res Clin Oncol 2002, 128: 85-90.

19. Ikeda Y, Swain A, Weber TJ, Hentges KE, Zanaria E, Lalli E, Tamai KT, Sassone-Corsi P, Lovell-Badge R, Camerino G, Parker KL: Steroidogenic factor 1 and Dax-1 colocalize in multiple cell lineages: potential links in endocrine development. $\mathrm{Mol}$ Endocrinol 1996, 10:1261-1272.

20. Lalli E, Sassone-Corsi P: DAX-1 an unusual orphan receptor at the crossroads of steroidogenic function and sexual differentiation. Mol Endocrinol 2003, 17:1445-1453.

21. Holter E, Kotaja N, Mäkela $S$, Strauss L, Kietz $S$, Jänne $O A$ Gustafsson JA, Palvimo J, Treuter E: Inhibition of androgen receptor (AR) function by the reproductive orphan nuclear receptor DAX-1. Mol Endocrinol 2002, 16:515-528.

22. UICC: TNM Classification of Malignant Tumour. Geneva: International Union Against Cancer; 1968.

23. Norton A, Jordan S, Yeomans P: Brief high-temperature heat denaturation (pressure cooking): a simple and effective method of antigen retrieval for routinely processed specimens. J Pathol 1994, 173:371-379.

24. Hsu SM, Soban E: Colour modification of diaminobenzidine (DAB) precipitation by metallic ions and its application for 
double immunohistochemistry. J Histochem Cytochem 1982, 30:1079-1082.

25. Shaw JA, Udokang $\mathrm{K}$, Mosquera JM, Chauhan $\mathrm{H}$, Jones JL, Walker RA: Oestrogen receptors alpha and beta differ in normal human breast and breast carcinomas. $J$ Pathol 2002, 198:450457.

26. Shoker BS, Jarvis C, Clarke RB, Anderson E, Hewlett J, Davies MP, Sibson DR, Sloane JP: Estrogen receptor-positive proliferating cells in the normal and precancerous breast. Am J Pathol 1999, 155:1811-1815.

27. Yamashita S: Localization and functions of steroid hormone receptors. Histol Histopathol 1998, 13:255-270.

28. Bjornstrom L, Sjoberg M: Signal transducers and activators of transcription as downstream targets of nongenomic estrogen receptor actions. Mol Endocrinol 2002, 16:2202-2214.

29. Mann S, Laucirica R, Carlson N, Younes PS, Ali N, Younes A, Li Y, Younes $\mathrm{M}$ : Estrogen receptor beta expression in invasive breast cancer. Human Pathol 2001, 32:113-118.

30. Dotzlaw H, Leygue E, Watson PH, Murphy LC: Expression of estrogen receptor- $\beta$ in human breast tumours. J Clin Endocrinol Metab 1997, 82:2371-2374.

31. Kuiper GG, Carlsson B, Grandien K, Enmark E, Haggblad J, Nilsson S, Gustafsson JA: Comparison of the ligand binding specificity and transcript tissue distribution of estrogen receptors alpha and beta. Endocrinology 1997, 138:863-870.

32. Hall JM, McDonnell DP: The estrogen receptor beta-isoform (ER beta) of the human estrogen receptor modulates ER alpha transcriptional activity and is a key regulator of the cellular response to estrogens and antiestrogens. Endocrinology 1999, 140:5566-5578.

33. Simpson ER: Aromatization of androgens in women: current concepts and findings. Fertil Steril 2002, 77:6-10.

34. Pasqualini JR: Role of androgens in breast cancer. $J$ Steroid Biochem Mol Biol 1993, 45:167-172.

35. Isola JJ: Immunohistochemical demonstration of androgen receptor in breast cancer and its relationship to other prognostic factors. J Pathol 1993, 170:31-35.

36. Jenster G, Van der Dorput JAGM, Van Vroonhoven C, van der Kwast TH, Trapman J Brinkmann AO: Domains of the human androgen receptor involved in steroid binding, transcriptional activation and nuclear binding. Mol Endocrinol 1991, 5:13901404.

37. Zhang $H$, Thomsen JS, Johansson L, Gustafsson JA, Treuter E: DAX-1 functions as an LXXLL-containing corepressor for activated estrogen receptors. J Biol Chem 2000, 275:3985539859.

38. Horvath LG, Henshall SM, Lee CS, Head DR, Quinn DI, Makela S, Delprado W, Golovsky D, Brenner PC, O'Neill G, Kooner R, Stricker PD, Grygiel JJ, Gustafsson JA, Sutherland RL: Frequent loss of estrogen receptor-beta expression in prostate cancer. Cancer Res 2001, 61:5331-5335.

\section{Correspondence}

Dr Ml Arenas, Department of Cell Biology and Genetics, University of Alcalá, 28871 Alcalá de Henares, Madrid, Spain. Tel: +34 91 8854798; fax: +34 91 8854799; e-mail: misabel.arenas@uah.es 